\title{
Pneumonia Due to a Rare Bacteria: Chryseobacterium Indologenes Infection in a Paediatric Patient
}

\author{
Nadir Bir Bakteriye Bağlı Pnömoni: \\ Pediatrik Bir Hastada Chryseobacterium Indologenes Enfeksiyonu \\ Tayfur Demiray ${ }^{1}$, Tuğba Ayhancı², Hüseyin Hatipoğlu², Halime Çiçek \\ Mehmet Köroğlu², Mustafa Altındiş ${ }^{2}$ \\ ${ }^{1}$ Department of Clinical Microbiology, Sakarya Research and Training Hospital, Sakarya, Turkey \\ ${ }^{2}$ Department of Medical Microbiology, School of Medicine, Sakarya University, Sakarya, Turkey \\ ${ }^{3}$ Department of Paediatric Diseases, School of Medicine Sakarya University, Sakarya, Turkey \\ Yazış̧ma Adresi / Correspondence:
}

Tayfur Demiray

Sakarya Üniversitesi Eğitim ve Araștırma Hastanesi, Adnan Menderes Bulvarı, Sağılk Sokak Mikrobiyoloji Laboratuvarı, Sakarya / TURKEY T: +905304662700 E-mail: tayfurdemiray@gmail.com

Orcid

Tayfur Demiray: https://orcid.org/0000-0003-1161-4684

Tuğba Ayhanc1: https://orcid.org/0000-0002-2115-6261

Hüseyin Hatipoğlu: https://orcid.org/0000-0001-9418-6691

Mehmet Köroğlu: https://orcid.org/0000-0001-8101-1104

Mustafa Altındiș: https://orcid.org/0000-0003-0411-9669

Halime Çiçek: https://orcid.org/0000-0001-9430-1995

Geliş Tarihi / Received : 10-04-2019 Kabul Tarihi / Accepted : 17-04-2019 Yayın Tarihi / Online Published: 30-04-2019

Demiray T., Ayhancı T., Hatipoğlu H., Köroğlu M., Altındiş M.

Pneumonia Due to a Rare Bacteria: Chryseobacterium indologenes Infection in a Paediatric Patient

J Biotechnol and Strategic Health Res. 2019;3(1):44-48 DOİ:10.34084/bshr.551982

Özet

Chryseobacterium indologenes is a non-fermantative yellow-pigmented Gram-negative bacillus and is widely distributed in nature. Chryseobacterium spp. can easily grow on wet surfaces and they are resistant to sanitation with chlorine to some degree, which causes them to colonize in hospital environments. C. indologenes is rarely isolated from human infections and is an emerging mult1-drug resistant microorganism. In this report, we present a rare microorganism, C. indologenes, isolated from tracheal secretions of a paediatric patient.

Anahtar Chryseobacterium indologenes, bacteremia, pneumonia 


\section{INTRODUCTION}

Chryseobacterium indologenes is a non-fermantative, catalase and oxidase positive, non-motile, yellow-pigmented Gram-negative bacillus ${ }^{1,2}$. It is widely distributed in nature especially in soil and water environments ${ }^{1,3}$. C. indologenes was belonging to Flavobacterium genus but recently it is classified as a member of Chryseobacterium genus ${ }^{2}$. Chryseobacterium can easily grow on wet surfaces and they are resistant to sanitation with chlorine to some degree, which causes them to colonize in hospital environments. They have been isolated as the etiologic agent of meningitis, pneumonia, bacteraemia, endocarditis, soft tissue infections and so on ${ }^{4}$. Infections due to the use of medical devices (respirators, humidifiers, incubators, etc.), which have contaminated fluids inside, have also been reported 5,6. Vast majority of the published cases of infections due C. indologenes have been described in paediatric age group who were immunocompromised patients with severe concomitant diseases or with indwelling devices ${ }^{1,7}$. Virulence capability of $C$. indologenes is often attributed to protease activity and biofilm production. However the other virulence factors and the complete mechanism pathogenicity still needs to be discovered ${ }^{8,9}$.

In this report, we present a rare microorganism, C. indologenes, isolated from tracheal secretions of a paediatric patient.

\section{CASE REPORT}

A 18-month-old male patient admitted to emergency clinic due to drowning in ornamental pool. He was intubated at the time of admission. He was unconscious and his eyes were fixed dilated. He had no spontaneous respiration. There upon he immediately transferred to paediatric intensive care unit where he was plugged to the mechanical ventilator and was monitored. Vital signs were as follows; temperature $36.1^{\circ} \mathrm{C}$, arterial blood pressure $94 / 60 \mathrm{~mm}$ Hg, White blood cell count 21800/ml, haemoglobin 14,9 $\mathrm{gr} / \mathrm{dl}$, erythrocyte sedimentation rate $3 / \mathrm{hr}$, glucose 353 $\mathrm{mg} / \mathrm{dl}$ detected as laboratory findings. Meropenem $60 \mathrm{mg} /$ $\mathrm{kg} /$ day was started empirically. At the seventh day of follow-up, the patient's fewer raised up to $38.6{ }^{\circ} \mathrm{C}$ and he suffered from huge amount of pulmonary secretions. Blood, urine and tracheal aspiration samples were collected. Pulmonary samples yielded Klebsiella pneumonia, which was sensitive to carbapenems, and the antimicrobial treatment was continued as it was. However, on the seventeenth day of the treatment vital signs of the patient were detoriated and the fewer again raised up to $38.4^{\circ} \mathrm{C}$ with C-reactive protein 6.05 . Blood and pulmonary samples were collected. Antimicrobial treatment was switched to tigecycline (3 $\mathrm{mg} / \mathrm{kg} /$ day). Both blood and tracheal aspiration samples yielded $C$. indologenes which was resistant to carbapenems and tigecycline but sensitive to trimethoprim/sulfametaxasol (TMP/SXT). Trimethoprim/sulfametaxasol (10 mg/ $\mathrm{kg} /$ day) was started. On the sixth day of TMP/SXT treatment, the treatment switched to tigesiklin after consulted to the infectious disease specialist. However, C. indologenes again yieleded from tracheal secretions of the patient. The antimicrobial treatment was changed to levofloxacin (10 $\mathrm{mg} / \mathrm{kg} /$ day). After ten days of treatment, infection due to C. indologenes was successfully treated. However the patient also suffered neurological disorders due to suffocation and transferred to other health care facility for further treatment.

\section{BACTERIAL METHODS}

Two tracheal aspiration samples and three consecutive blood samples yielded C. indologenes. In Gram stain of the pulmonary specimens, Gram-negative bacilli and inflammatory cells were observed abundantly. Typical yellow pigmented colonies were observed on the sheep blood agar plates (Figure). "MALDI-TOF MS (Matrix-assisted laser desorption ionization-time of flight mass spectrometry, Biomerieux, France)" for antimicrobial susceptibility testing. All of the five isolates were resistant to ampicilline, ampicilline/sulbactam, ticarciline/clavulonate, cephazolin, cefuroxime, ceftriaxone, ceftazidime, gentamisin and amikasin, colistin, imipenem and meropenem. They were detected as positive for ESBL. They were susceptible to lev- 


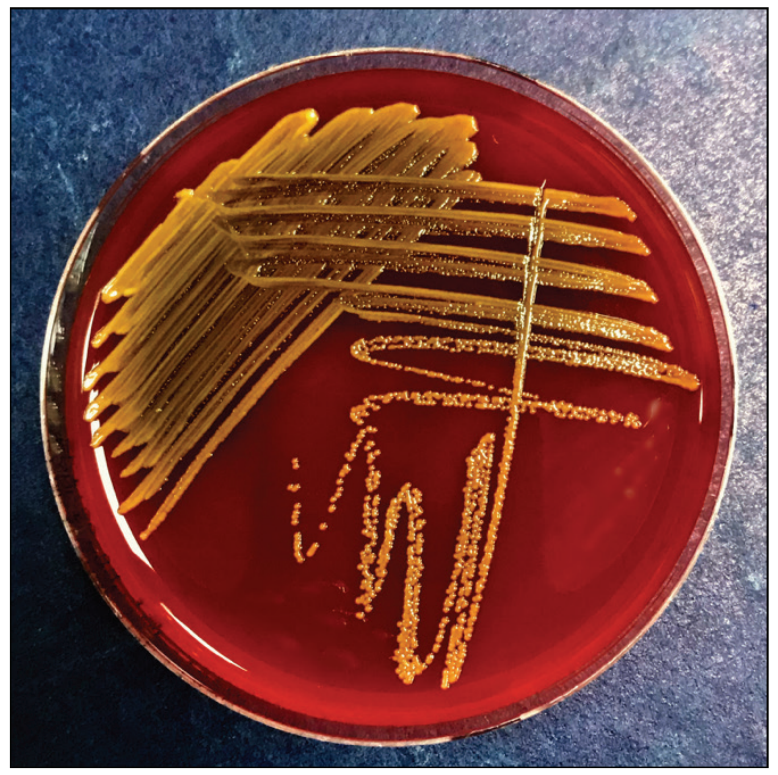

Figure: Typical yellow pigmented colonies of C. indologenes on $5 \%$ sheep blood agar plate.

\section{DISCUSSION}

C. indologenes is present in soil and is frequently isolated from wet surfaces in hospitals, but it is not a member of human microflora ${ }^{10}$. C. indologenes is accepted as a low virulent bacterium. In some experimental studies, Chryseobacterium can be rapidly eliminated by the host defence, when infused into the blood stream ${ }^{5,11,12}$. However, it has ability to survive in wet surfaces and it produces biofilm and proteases. It is also a multidrug resistant microorganism. All these factors cause this pathogen to cause life-threatening infections especially immune-compromised patients ${ }^{13-15}$. Bacteraemia, pneumonia, urinary tract infections, surgical wound infections, catheter-related infections, meningitis and peritonitis are most common infections that are caused due to C. indologenes ${ }^{16-20}$. Longterm indwelling catheters and devices, administration of long term antimicrobial therapy, immunodeficiency are the common risk factors detected in $C$. indologenes infections $^{8}$. In this case mechanical ventilation, indwelling catheters, previous wide spectrum antimicrobial treatment and patient age can be listed as risk factors.
Increasing use of automated identification systems enables more easily the identification of rare species. We use mass matrix-assisted laser desorption ionization-time of flight (Maldi-Toff) for identification. In a recent study, it is reported that the Vitek MS and Bruker Biotyper systems are successful to identify C. indologenes at the rates of $98.7 \%$ and $100 \%$, respectively. However both systems fails to determine the uncommon Chryseobacterium species other than C. indologenes ${ }^{21}$. Since C. indologenes is rarely isolated from human infections, very few data on antimicrobial susceptibility is present. The most reliable data about the antimicrobial susceptibility of the $C$. indologenes isolates are available from the SENTRY Antimicrobial Surveillance Program, which dates back to 1997-20014. According to the SENTRY program, the quinolones (gatifloxacin and levofloxacin) were most effective antimicrobials with susceptibility rates of $>95 \%$, followed by sulfamethoxazole/ trimethoprim (95\%), and piperacillin/tazobactam (90\%). Rifampicin, ceftazidim and cefepime displayed lesser but acceptable susceptibilities around $85 \%$. Other beta-lactam antibiotics, glycopeptides, aminoglycosides, chloramphenicol, carbapenems and linezolid were reported as ineffective for treatment. The presented case was successfully treated with levofloxacin. Broth dilution method is recommended over disk diffusion methods for susceptibility testing because results of disk diffusion tests are not reliable ${ }^{4}$. According to these limited data, quinolones and sulfamethoxazole/trimethoprim are the most appropriate antimicrobial options for the initial empirical treatment of the $C$. indologenes.

There are few reports about $C$. indologenes in paediatric age group. This report highlights the $C$. indologenes as an emerging mult1-drug resistant microorganism, especially in immunocompromised patients with additional risk factors such as indwelling catheters and prolonged antimicrobial treatment.

Conflict of interest: We attest that we have herein disclosed 
Journal of BSHR 2019;3(1):44-48

DEMİRAY, AYHANCI, HATIPPOĞLU, ÇiÇEK, KÖROĞLU, ALTINDİș Pneumonia Due to a Rare Bacteria: Chryseobacterium indologenes Infection in a Paediatric Patient

any and all financial or other relationships that could be construed as a conflict of interest and that all sources of financial support for this study have been disclosed and are indicated in the acknowledgments. All authors of this report declare no conflict of interest.

The contents of this manuscript are our original work and have not been published, in whole or in part, prior to or simultaneous with our submission of the manuscript to the journal. The manuscript has been read and approved for submission by all authors. All persons listed as authors have contributed to preparing the manuscript and/or that International Committee of Medical Journal Editors (ICMJE) criteria for authorship have been met, and that no person(s) other than the authors listed have contributed significantly to its preparation. 
Journal of BSHR 2019;3(1):44-48

DEMIRAY, AYHANCI, HATIPOĞLU, ÇIÇEK, KÖROĞLU, ALTINDIȘ Pneumonia Due to a Rare Bacteria: Chryseobacterium indologenes Infection in a Paediatric Patient

\section{References}

1. Lin JN, Lai CH, Yang CH, Huang YH, Lin HF and Lin HH. Comparison of four automated microbiology systems with $16 S$ rRNA gene sequencing for identification of Chryseobacterium and Elizabethkingia species Scientific Reports 2017 23;7(1):13824.

2. Mukerji R, Kakarala R, Smith SJ, Kusz HG. Chryseobacterium indologenes: an emerging infection in the USA. BMJ Case Rep. 2016. pii: bcr2016214486.

3. Antonello VS, Daht P, Polli J, Gross M and Colvero M. Ventilator-Associated Pneumonia In Neonatal Intensive Care Unit Due To Chryseobacterium Indologenes. The Pediatric Infectious Disease Journal 2017 36(12):353-355

4. Jeffrey T. Kirby, Helio S. Sader,Timothy R. Walsh, Ronald N. Jones. Antimicrobial Susceptibility and Epidemiology of a Worldwide Collection of Chryseobacterium spp.: Report from the SENTRY Antimicrobial Surveillance Program (1997-2001). J Clin Microbiol. 2004 ;42(1):445-8

5. Du Moulin GC. Airway colonization by Flavobacterium in an intensive care unit. J. Clin. Microbiol 1979 10:155-160.

6. Hoque SN, Graham J, Kaufmann ME, Tabaqchali S. Chryseobacterium (Flavobacterium) meningosepticum outbreak associated with colonization of water taps in a neonatal intensive care unit. J. Hosp. Infect. 2001 47:188-192.

7. Mehta R and Pathak A. Emerging Chryseobacterium indologenes Infection in Indian Neonatal Intensive Care Units: A Case Report. Antibiotics 2018, 7, 109

8. Chang YC, Lo HH, Hsieh HY, Chang SMI. dentification, epidemiological relatedness, and biofilm formation of clinical Chryseobacterium indologenes isolates from central Taiwan. J Microbiol Immunol Infect. 2015;48:559-64.

9. Hsueh PR, Hsiue TR, Wu JJ, Teng LJ, Ho SW, Hsieh WC et al. Flavobacterium indologenes bacteremia: Clinical and microbiological characteristics. Clin. Infect. Dis 1996 23, 550-555.

10. Bloch KC, Nadarajah R, and R. Jacobs. Chryseobacterium meningosepticum: an emerging pathogen among immunocompromised adults. Repor of 6 cases and literature review. Medicine (Baltimore) 1997 76:30-41.

11. Sader HS, Jones RN, and Pfaller MA. Relapse of catheterrelated Flavobacterium meningosepticum bacteremia demonstrated by DNA macrorestriction analysis. Clin. Infect. Dis 1995 21:997-1000.
12. Kirby JT, Sader HS, Walsh TR. Antimicrobial susceptibility and epidemiology of a worldwide collection of Chryseobacterium spp: report from the SENTRY Antimicrobial Surveillance Program (1997-2001). J of Clin Microbiol 2004;42:445-8.

13. Fraser SL, Jorgensen JH. Reappraisal of the antimicrobial susceptibilities of Chryseobacterium and Flavobacterium species and methods for reliable susceptibility testing. Antimicrob Agents Chemother 1997;41:2738-41.

14. Maravic A, Skocibusic M, Samanic I, Puizina J. Profile and multidrug resistanc determinants of Chryseobacterium indologenes from seawater and marine fauna. World J Microbiol Biotechnol 2013;29:515-22.

15. Afshar M, Nobakht E, Lew SQ. Chryseobacterium indologenes peritonitis in peritoneal dialysis. BMJ Case Rep. 2013: pii: bcr2013009410.

16. Green BT, Nolan PE. Cellulitis and bacteraemia due to Chryseobacterium indologenes. J Infect 2001;42:219-20.

17. Cone LA, Morrow AA, Benson M, et al. Chryseobacterium indologenes sepsis due to an infected central catheter in a patient with metastatic breast cancer to the skin. Infect Dis Clin Pract 2007;15:403-5.

18. Al-Tatari H, Asmar BI, Ang JY. Lumboperitonial shunt infection due to Chryseobacterium indologenes. Pediatr Infect Dis J. 2007;26:657-9.

19. Kilvington S, Shovlin J, Nikolic M. Identification and susceptibility to multipurpose disinfectant solutions of bacteria isolated from contact lens storage cases of patients with corneal infiltrative events. Cont Lens Anterior Eye 2013;36:294-8.

20. Sudharani V, Asiya, Saxena NK. Chryseobacterium indologenes bacteraemia in a preterm baby. Indian J Med Microbiol. 2011;29:196-8.

21. Lin JN, Teng SH, Lai CH, Yang CH, Huang YH et al. Comparison of the Vitek MS and Bruker Matrix-Assisted Laser Desorption Ionization-Time of Flight Mass Spectrometry Systems for Identification of Chryseobacterium Isolates from Clinical Specimens and Report of Uncommon Chryseobacterium Infections in Humans. J of Clin Microbiol. 2018, 56 (11) 00712-18 